\title{
Identification of Races of Bipolaris zeicola, the Causal Fungus of Helminthosporium Leaf Spot on Corn in Japan
}

\author{
Takao Tsukiboshi*, Takashi Kimigafukuro* and Toru Sato**
}

Key words : Bipolaris zeicola, race, corn.

In a previous report ${ }^{1)}$, we described the occurrence of Helminthosporium leaf spot on corn caused by Bipolaris zeicola (Stout) Shoem. in the northern part of Japan. In recent years, there has been a marked increase in the disease incidence and the disease is more prevalent than southern corn leaf blight in the Hokkaido District. In the present paper, we report the distribution and frequency of races of B. zeicola in Japan.

Three races have been differentiated in Helminthosporium leaf $\operatorname{spot}^{2,3}$. Isolates of race 1 produce large, zonate lesions on the corn lines sensitive to HC-toxin ${ }^{4}$. Isolates of race 2 produce chlorotic flecks or small, oval lesions, whereas race 3 isolates produce long, linear lesions. However, race 2 and race 3 do not produce HC-toxin and exhibit no host-specific pathogenicity, unlike race 1 . To identify race 1 isolates, N31, the inbred line which is susceptible to race 1 , was selected ${ }^{5)}$. Since the isolates of race 2 and race 3 occasionally produce similar symptoms, the inbred line, H93 was selected from 15 inbred lines based on the results of the preliminary experiment to identify race 2 and race 3 isolates.

The American isolates, NI1099, NI926 and NI848, were used as the inoculum of race 1 , race 2 and race 3 , respectively. Cultures were grown on $V-8$ juice agar at $23 \mathrm{C}$ in the dark for seven days. Approximately $5 \mathrm{ml}$ of each conidial suspension $\left(5-15 \times 10^{3}\right.$ spores $/ \mathrm{ml}$ ) prepared from the culture was sprayed on one plant at the 3-4 leaf stage. The inoculated plants were kept in a moist chamber at $23 \mathrm{C}$ for $16 \mathrm{hr}$ and then transferred to a daylight incubator under a $12 \mathrm{hr}$ light and $12 \mathrm{hr}$ dark regime at $23 \mathrm{C}$. Ratings of lesion types were made on the third and fourth leaves one week after inoculation, since the disease reactions were not consistent on the first and second leaves. Lesion type ratings for the inbred lines tested are presented in Table 1. The isolate of race 1 produced large, zonate lesions only on N31, but small, white and pin-hole like lesions on the other lines. The isolates of race 2 and race 3 produced fleck type and linear to zonate lesions on most of the lines, respectively. Especially on H93 and B37Ht, the characteristic lesions were consistently produced by both races (Fig. 1).

Identifiction of races of 43 Japanese isolates collected from the fields in 11 Prefec-

\footnotetext{
* National Grassland Research Institute 農水省草地試験場

** Hokkaido National Agricultural Experiment Station 農水省北海道農業試験場

1) Tsukiboshi, T. et al. (1986). Ann. Phytopath. Soc. Japan 52 : 492-495. 2) Ullstrup, A. J. (1940). Phytopathology $31: 508-521.3)$ Nelson, R. R. et al. (1973). Plant Dis. Reptr. $57: 822-823$. 4) Sheffer, R. P. and Ullstrup, A. J. (1965). Phytopathology $55: 1037-1038$. 5) Leonard, K. J. (1978). Can. J. Bot. $56: 1809-1815$.
} 
Table 1. Lesion type ratings for 15 inbred lines infected with race 1,2 and 3 of Bipolaris zeicola

\begin{tabular}{l|c|c|c}
\hline \multirow{2}{*}{ Inbred line } & \multicolumn{3}{|c}{ Race } \\
\cline { 2 - 4 } & race 1 & race 2 & race 3 \\
\hline A619Ht & $\mathrm{P}^{\mathrm{a})}$ & P-F & L-Z \\
A632Ht & $\mathrm{P}$ & P-F & L-Z \\
A632rhm & P & P-F & L-Z \\
B37Ht & P & F & L \\
H84 & P & P-F & L-Z \\
H93 & P & F & L \\
H95rhm & P & P-F & L-Z \\
H99 & P & F & L-Z \\
Mo17Ht & P & F-L & L-Z \\
N31 & Z & F-L & L-Z \\
Pa91 & P & P-F & Z \\
R2040 & P & F & L-Z \\
Va26Htht & P & P-F & L-Z \\
WF9 & P & F-L & L \\
WF9T & P & F-L & L \\
\hline
\end{tabular}

a) The lesion types shown as P, F, L and Z stand for pin-hole type lesion, fleck type lesion, linear lesion and zonate lesion, respectively.
Table 2. Frequencies of races and mating types among isolates of Bipolaris zeicola from different regions

\begin{tabular}{l|c|c|c|c|c}
\hline \hline \multirow{2}{*}{$\begin{array}{c}\text { Number of } \\
\text { isolates }\end{array}$} & \multicolumn{2}{|c|}{ Race } & \multicolumn{3}{c}{ Mating type } \\
\cline { 2 - 6 } District & race 2 & race 3 & A & a & infertile \\
\hline Hokkaido & 5 & 8 & 7 & 0 & 6 \\
Tohoku & 0 & 8 & 7 & 0 & 1 \\
Kanto & 0 & 10 & 5 & 1 & 4 \\
Tyubu & 1 & 10 & 8 & 0 & 3 \\
Kyusyu & 0 & 1 & 1 & 0 & 0 \\
\hline Total number & 6 & 37 & 28 & 1 & 14 \\
\hline
\end{tabular}

tures was performed, using the two differential lines, N31 and H93. Inoculation of each isolate was performed as described above. Seven days after inoculation, the differences in the symptoms on N31 and H93 enabled to identify the races. Simultaneously, the mating type of each isolate was determined by pairing with the testers, as previously described ${ }^{1}$. The results are

shown in Table 2. No isolate of race 1 was recovered from any of the regions surveyed presumably due to the wide-spread utilization of corn hybrids resistant to race 1 in Japan. The isolates of race 3 accounted for $86 \%$ of the isolates tested and predominated in all the regions surveyed. Six isolates of race 2 were recovered, although they were not as prevalent as those of race 3. However, the frequency of occurrence of race 2 isolates was very high in the Hokkaido District, accounting for $38 \%$ of the
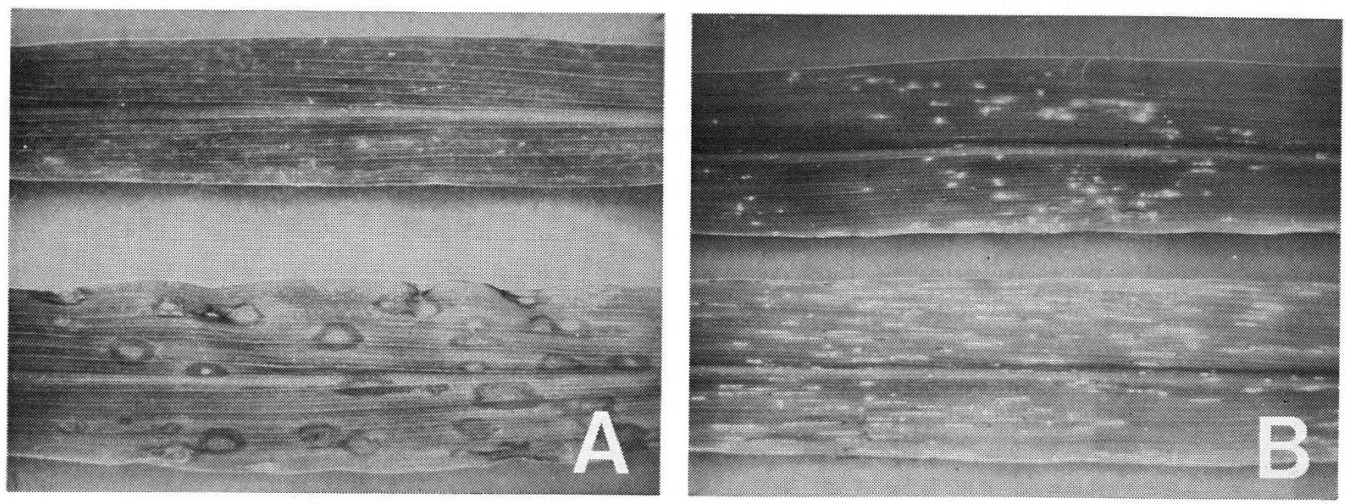

Fig. 1. Symptoms of Helminthosporium leaf spot on corn. (A) Symptoms produced by race 1 (NI1099) on H93, the resistant line (upper leaf) and N31, the susceptible line (lower leaf). (B) Symptoms produced by race 2 (NI926, upper leaf) and race 3 (NI848, lower leaf) on H93. 


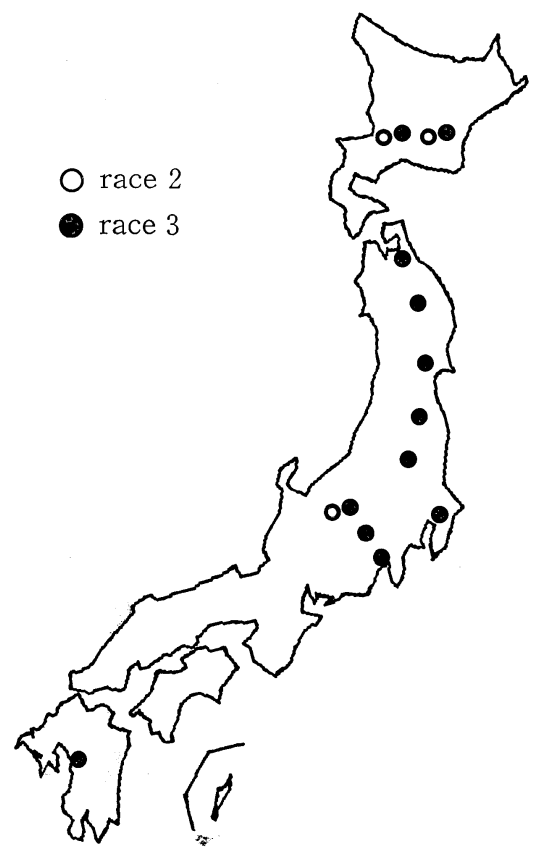

Fig. 2. Distribution of race 2 and race 3 of Bipolaris zeicola in Japan.

local population of B. zeicola. In Japan, B. zeicola was distributed mainly in the northern part of the country and one isolate was recovered from the Kyusyu District (Fig. 2).

With respect to the mating types, 28 isolates belonged to the A type, one to the a type and 14 were infertile with either tester. As reported by Leonard ${ }^{6)}$, the predominance of one mating type suggests the recent origin of $B$. zeicola in Japan. If sexual reproduction or mutation had occurred frequently, a more even distribution of the mating types would have been observed.

In the United States of America, the occurrence of race 1 is now limited, since the resistance to race 1 is conferred by a single dominant gene and readily incorporated into most of the commercial lines ${ }^{7,8)}$. However, the recent increase of the incidence of race 2 and race 3 is becoming a serious threat to corn production $^{9)}$. Since race 3 predominates in Japan, it

is essential to identify corn lines resistant to race 3.

We wish to express our thanks to Dr. K. J. Leonard, North Carolina State University, for supplying the isolates of B. zeicola.

\section{和 文 摘 要}

月星隆雄・君ケ袋尚志・佐藤 徹：トウモロコシ北方斑点病菌 Bipolaris zeicola のレース判別

トウモロコシ北方斑点病菌のレース判別を行った。本病菌は特定のトウモロコシ系統に輪紋型病斑を形成す るレース 1 ，フレック型病斑を形成するレース 2 および面線型病斑を形成するレース 3 亿分化している。てれ らレースのアメリカ産菌株をトウモロコシ自殖系統に噴蓩接種し, その病斑型から判別品種として N31 およ び H93 を選んだ。これを用いて, 11道県で採集した日本産43菌株のレース判別を行ったところ, 37菌株がレ 一ス 3，6菌株がレース 2 と判別され，レース 1 菌株は発見されなかった。レース 3 はいずれの調査地域でも 優占していたが, 北海道ではレース 2 の分離頻度がやや高かった。次に, 交配試験を行ったとてろ, 交配型 $\mathrm{A}$ が28菌株，aが 1 菌株であり，分布に偏りがみられたととから，本病が発生し始めてからまだ間がないと推察 された。

(Received May 23, 1987)

6) Leonard, K. J. (1971). Plant Dis. Reptr. $55: 759-760$. 7) Blanco, M. H. et al. (1974). Ibid. 55: 934-936. 8) Ullstrup, A. J. and Brunson, A. M. (1947). J. Am. Soc. Agron. 39 : 606-609.

9) Lodge, D. J. and Leonard, K. J. (1983). Can. J. Bot. 62:995-1005. 